Agricultural Journal 6(3): 119-123, 2011

ISSN: $1816-9155$

(C) Medwell Journals, 2011

\title{
Effect of Dietary Probiotic Level on the Reproductive Performance of Female Platy Xiphophorus maculatus
}

\author{
Hajibeglou Abasali and Sudagar Mohamad \\ Department of Fishery Sciences, \\ University of Agricultural Sciences and Natural Resources of Gorgan, \\ P. O. Box: 49138-15749, Golestan, Iran
}

\begin{abstract}
A commercial probiotic, Primalac was incorporated in fish feed at four different concentrations of 0.0 , $0.04,0.09$ and $0.14 \%$ and fed to platy Xiphophorus maculatus for a period of 26 weeks to observe the effect of dietary probiotic supplementation on their reproductive performance. Results indicated that female broodstock fed the diets supplemented with primalac showed enhanced Gonadosomatic Index (GSI) and fry production compared to the control group $(\mathrm{p}<0.01)$. There were no significant differences in the percentage of deformed fry and fry weight among the dietary treatments $(\mathrm{p}>0.05)$. The results also showed that fecundity, fry survival $(\%)$ and length of fry were significantly $(\mathrm{p}<0.01)$ higher in experimental groups (except the group fed $0.04 \%$ Primalac mixed diet) compared to the control group ( $\mathrm{p}<0.01$ ). It can be conducted that the probiotic Primalac we used in this study can improve the reproductive performance of female platy-fish broodstocks during reproductive stages.
\end{abstract}

Key words: Primalac, probiotic, Xiphophorus maculatus, reproductive performance, gonadosomatic index, fry

\section{INTRODUCTION}

There is a growing commercial interest in the ornamental fish trade in Asia and all over the world. The annual international fish in 2002 were about US $\$ 200$ million in value (Vannuccini, 2004). Live bearing species from the family poeciliidae like platies (Xiphophorus maculatus) are a very popular group of ornamental fish species because of the fact that they are brightly colored, accepted all kinds of food and breed prolifically to produce living free swimming young ones (Ling et al., 2006; Ghosh et al., 2007). Poeciliid species demonstrate viviparous breeding strategy with females storing transferred sperms within the ovary followed by internal egg fertilization and hatching of youngs (Chong et al., 2004).

Broodstock nutrition and the interaction between nutrients and reproductive performance are still poorly understood due to difficulties in conducting studies involving proper feeding and reproduction of broodstock (Chong et al., 2004). Hormones, nutrient mixtures, antibiotics, chemotherapeutants and herbal products are used as nutrient supplements for broodstock of ornamental fish. But there are major limitations to the general use of these agents such as increased risk of suppression of the beneficial microbial activity in the intestinal tract of the breeders. Hence, the breeders easily become prone to disease by the opportunistic pathogens (Ghosh et al., 2007). Moreover, the indiscriminate use of antibiotics and chemotherapeutants for improved health and nutrition has been criticized because their use has created problems with drug resistance bacteria, toxicity and accumulation both in fish and environment (Amabile-Cuevas et al., 1995; Ghosh et al., 2008). Probiotics seem to represent a useful alternative to repair these deficiencies.

Probiotics, live microbes that may serve as dietary supplements to improve the intestinal microbial balance have received some attention in aquaculture (Gatesoupe, 1999; Irianto and Austin, 2002; Li and Gatlin, 2004). There are several possible mechanisms to explain the modes of action of probiotic bacteria.

The competitive exclusion, based on the removal of the pathogen by beneficial population is believed to plays an important role in this process (Gatesoupe, 1999; Ghosh et al., 2008). Furthermore, many researchers showed that the enhancement of animal growth can be attributed to the nutritional benefits of probiotic bacteria such as vitamin production, availability of minerals and trace elements and production of important digestive

Corresponding Author: Hajibeglou Abasali, Department of Fishery Sciences, University of Agricultural Sciences and Natural Resources of Gorgan, P. O. Box: 49138-15749, Golestan, Iran 
enzymes (Helerer et al., 1998; Ghosh et al., 2008). Although, the effect of probiotics on fish growth performance and resistance to disease has been well studied (Bogut et al., 1998; Robertson et al., 2000; Rengipipat et al., 2000; Ghosh et al., 2007, 2008). Research on the effect of feeding probiotics on reproductive performance of fish is elusive and has only poorly been studied yet (Ghosh et al., 2007). Therefore, the objective of the present experiment was to investigate the effects of dietary Primalac (a commercial probiotic) levels on various reproductive aspects of platy (Xiphophorus maculatus).

\section{MATERIALS AND METHODS}

Probiotics: A commercial probiotic Primalac, a mixture of equal proportions of Lactobacillus acidophilus, Lactobacillus casei, Enterococcus faecium and Bifidobacterium thermophilum was obtained from the Nikandishan Farjad Commerce Corporation, Tehran, Iran.

Preparation of test diets: The experimental diets were prepared by incorporating Primalac to the feeds in the concentration of $0.04 \%(\mathrm{~B}), 0.09 \%(\mathrm{C})$ and $0.14 \%(\mathrm{D})$ of the diets (Table 1). Control diet (A) was also prepared using the same composition of ingredients except Primalac. To prepare the diets, first, ingredients were blended thoroughly with additional water and $1 \%$ binder to make a paste of each diet. The pastes were then cold extruded and cut into pellets. The diets were air-dried and stored at $-2^{\circ} \mathrm{C}$ (Sardar et al., 2007) in tight containers until use.

Fish: About 1 month old juveniles of platies (Xiphophorus maculatus) were purchased from a commercial fish farm at Gorgan, Golestan, Iran. They were kept in $500 \mathrm{~L}$ plastic containers with recirculated and aerated water for 3 months until they reached sexual maturity. They were fed with basal experimental diet (Table 1) without supplementation of the Primalac at 5\% of their body weight daily in 2 split doses. Throughout this period, males were separated from females at earliest sign of sexual differentiation to avoid reproductive activities. Female poecilidae can retain active sperm in crypts in their ovaries and oviduct for a period of up to 8 months and become pregnant without another copulation (Dzikowski et al., 2001; Ghosh et al., 2007). Therefore, only virgin females were used for this study.

Experimental design and feeding diet: Virgin females aged 4 months (average weight 0.60-0.61 g and length 3.2-3.3 mm) were used for experiment. Fish were divided randomly into four groups (A-D). Total 4 replicate tanks
Table 1: Formulation (dry weight $\%$ ) and chemical composition of the experimental diets

\begin{tabular}{|c|c|c|c|c|}
\hline \multirow[b]{2}{*}{ Compositions } & \multicolumn{4}{|l|}{ Diet } \\
\hline & A (control) & $\mathrm{B}$ & $\mathrm{C}$ & $\mathrm{D}$ \\
\hline \multicolumn{5}{|l|}{ Ingredients (\%) } \\
\hline Fish meal $^{\mathrm{a}}$ & 40 & 40 & 40 & 40 \\
\hline Whole wheat meal & 10 & 10 & 10 & 10 \\
\hline Barley meal & 10 & 10 & 10 & 10 \\
\hline Soybean meal & 14 & 14 & 14 & 14 \\
\hline Corn meal & 10 & 10 & 10 & 10 \\
\hline Fish oil ${ }^{b}$ & 5 & 5 & 5 & 5 \\
\hline Sunflower oil & 3 & 3 & 3 & 3 \\
\hline Soybean oil & 3 & 3 & 3 & 3 \\
\hline Lecitine $^{c}$ & 2 & 2 & 2 & 2 \\
\hline Vitamin premix ${ }^{d}$ & 1 & 1 & 1 & 1 \\
\hline Mineral premix ${ }^{e}$ & 1 & 1 & 1 & 1 \\
\hline $\mathrm{Ca}\left(\mathrm{H}_{2} \mathrm{PO}_{4}\right)_{2}$ & 0.75 & 0.75 & 0.75 & 0.75 \\
\hline Chromic oxide ${ }^{f}$ & 0.25 & 0.25 & 0.25 & 0.25 \\
\hline Prebiotic immunogen ${ }^{g}$ & 0.00 & 0.50 & 1 & 1.50 \\
\hline \multicolumn{5}{|c|}{ Proximate chemical composition ${ }^{\text {h }}$} \\
\hline Crude protein & 34.90 & 34.81 & 34.65 & 34.84 \\
\hline Crude lipid & 16.30 & 16.37 & 16.41 & 16.45 \\
\hline Ash & 10.41 & 10.71 & 10.45 & 10.25 \\
\hline Moisture & 8.400 & 8.20 & 8.40 & 8.10 \\
\hline Gross energy $\left(\mathrm{kcal} \mathrm{g}^{-1}\right)$ & 5.450 & 5.44 & 5.44 & 5.45 \\
\hline
\end{tabular}

${ }^{a}$ Fish meal: Pars kelika Co., Mirood, Iran; ${ }^{b}$ Herring oil; ' ${ }^{\mathrm{c}}$ Aquagran, Riceland (USA); dvitamin premix contained the following vitamins (each kg-1 diet): vitamin A, $10,000 \mathrm{IU}$; vitamin $\mathrm{D}_{3}, 2000 \mathrm{IU}$; vitamin $\mathrm{E}, 100 \mathrm{mg}$; vitamin $\mathrm{K}, 20 \mathrm{mg}$; vitamin $\mathrm{B}_{1}, 400 \mathrm{mg}$; vitamin $\mathrm{B}, 40 \mathrm{mg}$; vitamin $\mathrm{B}_{6}, 20 \mathrm{mg}$; vitamin $\mathrm{B}_{12}, 0.04 \mathrm{mg}$; biotin, $0.2 \mathrm{mg}$; choline chloride, $1200 \mathrm{mg}$; folic acid, $10 \mathrm{mg}$; inositol, $200 \mathrm{mg}$; niacin, $200 \mathrm{mg}$; pantothenic calcium, $100 \mathrm{mg}$. Contained ( $\mathrm{g} \mathrm{kg}^{-1}$ mix): $\mathrm{MgSO}_{4} .2 \mathrm{H}_{2} 0,127.5 ; \mathrm{KCl}, 50.0 ; \mathrm{NaCl}, 60.0$; $\mathrm{CaHPO}_{4}, 2 \mathrm{H}_{2} \mathrm{O}, 727.8 ; \mathrm{FeSO}_{4} .7 \mathrm{H}_{2} \mathrm{O}, 25.0 ; \mathrm{ZnSO}_{4} .7 \mathrm{H}_{2} \mathrm{O}, 5.5 ; \mathrm{CuSO}_{2} 5 \mathrm{H}_{2} \mathrm{O}$, $0.785 ; \mathrm{MnSO}_{4} .4 \mathrm{H}_{2} \mathrm{O}, 2.54 ; \mathrm{CoSO}_{4} .4 \mathrm{H}_{2} \mathrm{O}, 0.478 ; \mathrm{Ca}\left(\mathrm{IO}_{3}\right)_{2} .6 \mathrm{H}_{2} \mathrm{O}, 0.295$; $\mathrm{CrCl}_{3}, 6 \mathrm{H}_{2} \mathrm{O}$, 0.128. 'figma aldrich company, poole, Dorset, UK ${ }^{\mathrm{g}}$ International Commerce Corporation USA, INC. ${ }^{\mathrm{h}}$ Expressed as percent dry matter unless indicated otherwise

$(60 \mathrm{~L})$ were used for evaluation of each diet with a total of 10 females selected and stocked in each tank. Group A received the basal diet acted as control. Group B-D were fed with probiotic Primalac at $0.04,0.09$ and $0.14 \%$ of feed, respectively.

The fish were fed with feed at $5 \%$ of their body weight daily in 2 split doses throughout the experimental period at 09:00 and 17:00 h. The feeding trial lasted for 26 weeks. Virgin males aged 4 months were kept separately in a large tank (250 L) and fed frozen bloodworms (Hikari ${ }^{\circledR}$, Hayward, CA, USA) twice daily.

During the experimental period, three males were randomly selected and introduced into each of the 4 different groups at an interval of 30 days. These males were left with the females for 5 days before returning them to the holding tank. The wastes and fecal matter were siphoned out on every 3rd day.

During feeding, males were separated from females using plastic sheet, bundles of tied-nylon strings were placed into each experimental tank as shelter for new free-swimming fry to avoid cannibalism by parental fish. The water quality parameters were monitored every day and maintained at optimal level by regular water 
exchange (temperature, $24.3^{\circ} \mathrm{C} \pm 1.5$; dissolved oxygen, $7.1 \pm 0.52 \mathrm{mg} \mathrm{L}^{-1}$; salinity, $0.43 \pm 0.07 \mathrm{ppt}$; $\mathrm{pH}, 7.65 \pm 0.21$ units; ammonia-nitrogen $<0.18$ ).

Proximate composition of diet: Analysis of dry matter (by oven drying at $105^{\circ} \mathrm{C}$ for $24 \mathrm{~h}$ ), crude lipid (extraction with petroleum ether by Soxhlet apparatus), crud protein (Kjeldahl apparatus, nitrogen $\times 6.25$ ) and ash (incineration in a muffle furnace at $600^{\circ} \mathrm{C}$ for $4 \mathrm{~h}$ ) were performed for feed (AOAC, 2000).

Reproductive parameters: Reproductive performances were calculated as follows: Relative fecundity $=$ Total fry production at throughout experimental period/mean weight of female $(\mathrm{g})$. Total fry production per female $=$ Total fry harvested throughout experimental period per number of female. Gonadosomatic index $(\%)=($ Ovary weight/body weight $) \times 100$. Survival $(\%)=($ Total live fry (no.) after t/total fry production (no.) throughout experimental period) $\times 100$ where, $t$ is the days of experiment.

Statistical analysis: All data obtained from experiments were analyzed by a one-way Analysis of Variance (ANOVA) using the SAS (2002-2003) package. Differences among means were determined and compared by LSD's test. Significance was also set at $5 \%$ level.

\section{RESULTS}

Mean total fry production per female in the 3 experimental groups was significantly $(\mathrm{p}<0.01)$ higher than control group (Fig. 1). In addition, there was no significant difference ( $p>0.01$ ) between group $C$ and $D$. The results of the relative fecundity of different experimental groups are shown in Fig. 2. Relative fecundity was lowest for the control group $\mathrm{A}$ followed by group $\mathrm{B}$ while group $\mathrm{C}$ and D showed the highest levels.

The results of the Gonadosomatic Index (GSI) are shown in Fig. 3. Although, the GSI of fish fed the probiotic feeds (experimental groups B-D) were significantly higher $(\mathrm{p}<0.01)$ than fish fed the control feed, the differences among experimental groups B-D were not significant $(p>0.01)$. The average length of fry in the experimental groups $\mathrm{C}$ and $\mathrm{D}$ were found to differ significantly $(\mathrm{p}<0.01)$ from that in the experimental groups $\mathrm{B}$ and A (Table 2). While there were no significant differences in the weight of fry among the different dietary treatment (Table 2). The dietary intake of probiotic Primalac had no significant $(\mathrm{p}>0.05)$ impact on the percentage of deformed fry of $X$. maculatus within the treated groups and control group (Table 2).

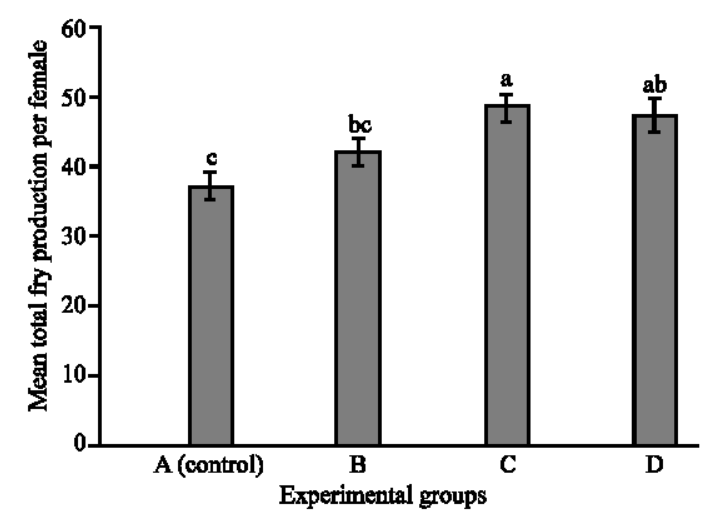

Fig. 1: Total fry production per female of different experimental groups of Xiphophorus maculatus; means with the same letters are not significantly different $(p>0.05)$; data are expressed as mean \pm S.E

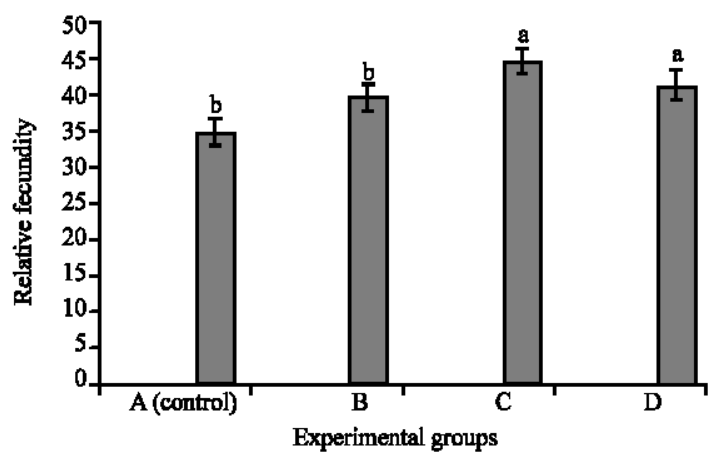

Fig. 2: Relative fecundity of different experimental groups of Xiphophorus maculatus; means with the same letters are not significantly different ( $p>0.05$ ); data are expressed as mean \pm S.E

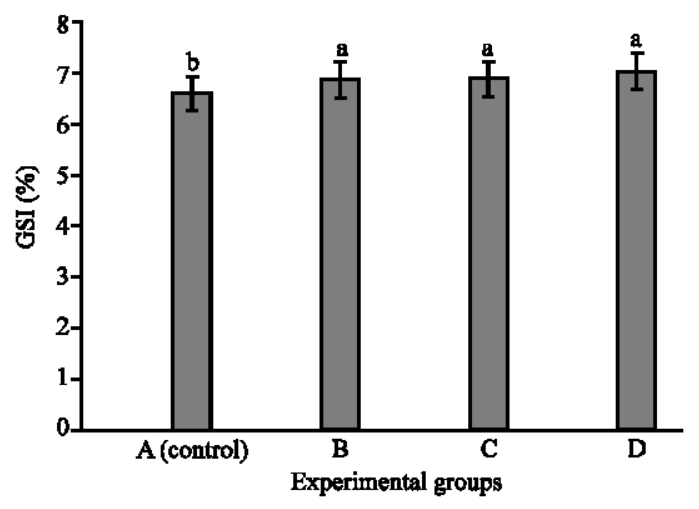

Fig. 3: Gonadosomatic index (\%) of different experimental groups of Xiphophorus maculatus; data are expressed as mean \pm S.E; values receiving same superscript are statistically not significant $(\mathrm{p}>0.05)$ 
Table 2: The percentage of deformed fry and average weight and length of fry in different experimental groups of Xiphophorus maculatus

\begin{tabular}{llccc}
\hline $\begin{array}{l}\text { Experimental } \\
\text { groups }\end{array}$ & $\mathrm{A}$ (control) & $\mathrm{B}$ & $\mathrm{C}$ & $\mathrm{D}$ \\
\hline Fry length (mm) & $6.32 \pm 0.005^{\mathrm{b}}$ & $6.29 \pm 0.012^{\mathrm{b}}$ & $6.34 \pm 0.012^{\mathrm{b}}$ & $6.56 \pm 0.026^{\mathrm{a}}$ \\
Fry weight (mg) & $2.23 \pm 0.033^{\mathrm{b}}$ & $2.36 \pm 0.066^{\mathrm{b}}$ & $2.33 \pm 0.033^{\mathrm{b}}$ & $2.46 \pm 0.033^{\mathrm{a}}$ \\
Deformed fry (\%) & $3.97 \pm 0.654^{\mathrm{a}}$ & $4.89 \pm 1.211^{\mathrm{b}}$ & $4.15 \pm 0.770^{\mathrm{a}}$ & $2.37 \pm 1.190^{\mathrm{a}}$ \\
\hline
\end{tabular}

Means with the same letters in each row are not significantly different $(p>0.05)$; data are expressed as mean \pm S.E

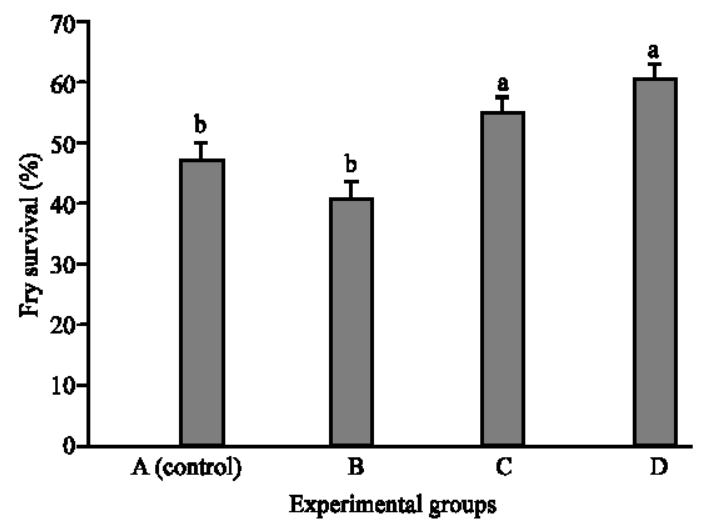

Fig. 4: Fry survival (\%) of different experimental groups of Xiphophorus maculatus; data are expressed as mean \pm S.E; values receiving same superscript are statistically not significant $(\mathrm{p}>0.05)$

The fish of experimental groups $\mathrm{B}$ and $\mathrm{D}$ recorded the lowest and highest fry survival $(\%)$, respectively. The percentage of fry survival in the experimental groups $\mathrm{C}$ and D were found to differ significantly $(p<0.01)$ from that groups A and B (Fig. 4).

\section{DISCUSSION}

Several studies have shown that probiotic bacteria enhance nutrition by synthesizing essential nutrients (vitamins, proteins and essential fatty acids) and enzymes (amylase, protease and lipase) (Gatesoupe, 1999; Irianto and Austin, 2002; Ghosh et al., 2007, 2008). Probiotic bacteria can enhance host enzyme secretion which increases the digestive efficacy of the complex proteins and lipids included in the diet thus, increasing food digestion and absorption by the host (Tovar et al., 2002; Ghosh et al., 2007, 2008).

There is a positive correlation between the presence of proteins and fatty acids in the broodstoock diet and reproductive-related factors such as better oocyte development and maturation, higher rate of vitellogenesis and larger egg size (Milton and Arthington, 1983; Shim et al., 1989; Seghal and Toor, 1991; Ghosh et al., 2007; Dahlgren, 1980; Ling et al., 2006). This present study demonstrated that Primalac supplemented diets significantly influenced the gonadosomatic index, fry production, relative fecundity and fry survival. These revealed that the probiotic incorporated diets helped to increase the reproductive performance of the experimental fish. This is in agreement with the report of Ghosh et al. (2007) that reproductive performance was enhanced in the probiotic feed fed fish.

These could be attributed to the balanced production of essential nutrients (in particular essential fatty acids) by intestinal probiotic bacteria (Irianto and Austin 2002; Ghosh et al., 2007). Several studies have shown the importance of balancing the composition of dietary unsaturated fatty acids such as arachidonic acid, docosahexaenoic acid and eicosapentaenoic acid in fish to ensure optimized broodstock reproductive performances and enhance larval quality (Sargent, 1995; Mazorra et al., 2003; Ling et al., 2006).

Moreover, essential fatty acids can also supply energy to sustain the spawning activities (Ling et al., 2006; Ghosh et al., 2007). Probiotic bacteria also affect the production of the vitamins, particularly $B$ group vitamins (Goldin and Gorbach, 1992; Ghosh et al., 2007). Hence, higher survival rate could be linked to the intestine probiotic bacteria which produce $B$ group vitamins.

Ghosh et al. (2007) reported that the synthesis of vitamin $B_{1}$ and $B_{12}$ by the probiotic bacterial strain, Bacillus subtilis could have accounted for the reduced numbers of dead fry in 4 species of livebearing ornamental fish fed diets containing B. subtilis. These observations are in agreement with the finding of Ketola et al. (1998) who reported that thiamin (vitamin $\mathrm{B}_{1}$ ) can reduce the mortality of progeny in the Atlantic salmon.

\section{CONCLUSION}

The commercial probiotic (Primalac) we used in this study considerably could enhance the reproductive performance of Xiphophorus maculatus.

\section{ACKNOWLEDGEMENT}

The researchers are thankful to Dr. A.R. Hajibeglou for his help during the experiment.

\section{REFERENCES}

AOAC, 2000. Official Method of Analysis of the Association of Analytical Chemists. 17th Edn., Association of Official Analytical Chemists, Washington, DC. USA.

Amabile-Cuevas, C.F., M. Gardenas-Garcia and M. Ludgar, 1995. Antibiotic resistance. Am. Sci., 83: $320-329$. 
Bogut, I., Z. Milakovic, Z.I. Bukvic, S. Brkic and R. Zimmer, 1998. Influence of probiotic (Streptococcus faecium M74) on growth and content of intestinal microflora in carp (Cyprinus carpio). Czech J. Anim. Sci., 43: 231-235.

Chong, A.S.C., S.D. Ishak, Z. Osman and R. Hashim, 2004. Effect of dietary protein level on the reproductive performance of female swordtails Xiphophorus helleri (Poeciliidae). Aquaculture, 234: 381-392.

Dahlgren, B.T., 1980. The effects of three different dietary protein levels on the fecundity in the guppy, Poecilia reticulate (Peters). J. Fish Biol., 16: 83-97.

Dzikowski, R., G. Hulata, I. Karplus and S. Harpaz, 2001. Effect of temperature and dietary L-carnitine supplementation on reproductive performance of female guppy (Poecilia reticulata). Aquaculture, 199: 323-332.

Gatesoupe, F.J., 1999. The use of probiotics in aquaculture. Aquaculture, 180: 147-165.

Ghosh, S., A. Sinha and C. Sahu, 2007. Effect of probiotic on reproductive performance in female livebearing ornamental fish. Aquacult. Res., 38: 518-526.

Ghosh, S., A. Sinha and C. Sahu, 2008. Dietary probiotic supplementation in growt and healt of live-bearing ornamental fishes. Aquacult. Nutr., 14: 289-299.

Goldin, B.R. and S.L. Gorbach, 1992. Probiotics for Humans. In: Probiotics: The Scientific Basis, Fuller, R. (Ed.). Chapman and Hall, New York, USA., pp: 355-376.

Helerer, P., J. Snel, U. Schillinger and J.H. Huisin't Veld, 1998. Overview of gut flora and probiotics. Int. J. Food Microbiol., 41: 85-101.

Irianto, A. and B. Austin, 2002. Probiotics in aquaculture. J. Fish Dis., 25: 633-642.

Ketola, H.G., P.R. Bowser, L.R. Wooster, L.R. Wedge and $\mathrm{S}$. Hurst, 1998. Thiamin remediation of early mortality in fry of Atlantic salmon from Cayuga Lake. Great Lakes Res. Rev., 3: 21-26.

Li, P. and D.M. Gatlin, 2004. Dietary brewers yeast and the prebiotic Grobiotic ${ }^{\mathrm{TM}} \mathrm{AE}$ influence growth performance, immune responses and resistance of hybrid striped bass (Morone chrysops $\times$ M. saxatilis) to Streptococcus iniae infection. Aquaculture, 231: 445-456.

Ling, S., R. Hashim, S. Kolkovski and A.C. Shu-Chien, 2006. Effect of varying dietary lipid and protein levels on growth and reproductive performance of female swordtails Xiphophorus helleri (Poeciliidae). Aquacult. Res., 37: 1267-1275.
Mazorra, C., M. Bruce, J.G. Bell, A. Davie and E. Alorend et al., 2003. Dietary lipid enhancement of broodstock reproductive performance and egg and larval quality in Atlantic halibut (Hippoglossus hippoglossus). Aquaculture, 227: 21-33.

Milton, D.A. and A.H. Arthington, 1983. Reproductive biology of Gambusia affinis holbrooki Baird and Girard, Xiphophorus heleri (Gunther) and $X$. maculatus (Heckel) (Pisces: Poecillidae) in Queensland, Australia. J. Fish Biol., 23: 23-41.

Rengipipat, S., S. Rukpratanporn, S. Piyatiratitivorakul and P. Menasaveta, 2000. Immunity enhancement in black tiger shrimp (Penaeus monodon) by a probiotic bacterium (Bacillus S11). Aquaculture, 191: 271-288.

Robertson, P.A.W., C.O. Dowd, C. Burrells, P. Williams and B. Austin, 2000. Use of Carnobacterium sp. as a probiotic for Atlantic salmon (Salmo salar L.) and rainbow trout (Oncorhynchus mykiss, Walbaum). Aquaculture, 185: 235-243.

Sardar, P., H.S. Randhawa, M. Abid and Prabhakar, 2007. Effect of dietary microbial phytase supplementation on growth performance, nutrient utilization, body compositions and haemato-biochemical profiles of Cyprinus carpio (L.) fingerlings fed soyproteinbased diet. Aquacult. Nutr., 13: 444-456.

Sargent, J.R., 1995. Origins and Functions of Egg Lipids: Nutritional Implications. In: Broodstock Management and Larval Quality, Bromage, N.R. and R.J. Roberts (Eds.). Blackwell, Oxford, UK., pp: 353-372.

Seghal, H.S. and H.S. Toor, 1991. Offspring fitness and fecundity of an Indian major carp, Labeo rohita (Ham.) in relation to egg size. Aquaculture, 97: 269-279.

Shim, K.F., L. Landesman and T.J. Lam, 1989. Effect of dietary protein on growth ovarian development and fecundity in the dwarf gourami Colisa lalia (Hamilton). J. Aquacult. Tropics, 4: 111-123.

Tovar, D., J. Zambonino, C. Cahu, F.J. Gatesoupe, R. Vazquez-Juarez and R. Lesel, 2002. Effect of live yeast incorporation in compound diet on digestive enzyme activity in sea bass (Dicentrarchus labrax) larvae. Aquaculture, 201: 113-123.

Vannuccini, S., 2004. Overview of Fish Production, Utilization, Consumption and Trade. Food and Agriculture Organization of the United Nations, Rome, Italy. 